\title{
IMPLEMENTASI MODEL PEMBELAJARAN RECIPROCAL TEACHING UNTUK MENINGKATKAN HASIL BELAJAR TEKNOLOGI DASAR OTOMOTIF PESERTA DIDIK KELAS X TKRO 2 SMK MUHAMMADIYAH 1 BANTUL
}

\author{
Dimas Ari Prasetyo \\ SMK Muhammadiyah 1 Patuk Yogyakarta \\ *Corresponding Author: prasetyodimasari@gmail.com
}

\begin{abstract}
This research aims to improve the learning outcomes on Basic Technology of Automotive course of the grade X student TKRO 2 in SMK Muhammadiyah 1 Bantul through the implementation of the Reciprocal Teaching learning model. This research is a Classroom Action Research (CAR) that is implemented in 2 cycles which is 2 meetings in each cycle. The research was conducted on January 14th, 2020 until February 4th, 2020 at SMK Muhammadiyah 1 Bantul. The subject of this research is 32 TKRO 2 grade X students of basic automotive technology in SMK Muhammadiyah 1 Bantul in even semester of academic year 2019/2020. The data collection using observation sheets was used for observing the implementation of the Reciprocal Teaching learning model and evaluation of learning outcomes tests to determine student learning outcomes. The data analysis technique used is quantitative data analysis technique. This research was categorized as success when the when the percentage of completeness of student learning outcomes by $75 \%$ (good category) the minimum score of learning outcomes is 78. The results of the research showed that the implementation of the Reciprocal Teaching learning model on the teaching-learning process can improve the learning outcomes on Basic Technology of Automotive course of the grade X student TKRO 2 in SMK Muhammadiyah 1 Bantul. This is proven of the student learning outcomes on cycle I that is $55.17 \%$ (less category) on cycle II increased to $82.76 \%$ (very good category).
\end{abstract}

Keywords: Reciprocal Teaching, Learning Outcomes, Basic Technology of Automotive

\begin{abstract}
Abstrak
Penelitian ini bertujuan untuk meningkatkan hasil belajar Teknologi Dasar Otomotif peserta didik kelas X TKRO 2 SMK Muhammadiyah 1 Bantul melalui implementasi model pembelajaran Reciprocal Teaching. Penelitian ini adalah penelitian tindakan kelas (PTK) dan dilaksanakan selama dua siklus yang masing-masing siklus terdiri dari 2 kali pertemuan. Penelitian dilaksanakan pada 14 Januari 2020 sampai dengan 4 Februari 2020 di SMK Muhammadiyah 1 Bantul. Subyek penelitian ini adalah peserta didik kelas X TKRO 2 SMK Muhammadiyah 1 Bantul semester genap tahun ajaran 2019/2020 yang berjumlah 32 peserta didik. Pengambilan data menggunakan lembar observasi untuk mengamati pelaksanaan model pembelajaran Reciprocal Teaching dan tes evaluasi hasil belajar untuk mengetahui hasil belajar peserta didik. Teknik analisis data yang digunakan adalah teknik analisis data kuantitatif. Penelitian ini dikatakan berhasil apabila persentase ketuntasan hasil belajar peserta didik sebesar 75\% (kategori baik) yaitu nilai hasil belajar minimal 78. Hasil penelitian menunjukkan bahwa implementasi model pembelajaran Reciprocal Teaching pada proses pembelajaran mampu meningkatkan hasil belajar Teknologi Dasar Otomotif peserta didik kelas X TKRO 2 SMK Muhammadiyah 1 Bantul. Hal ini terbukti pada siklus I persentase ketuntasan hasil belajar peserta didik sebesar 55,17\% (kategori kurang) pada siklus II meningkat menjadi 82,76\% (kategori sangat baik).
\end{abstract}

Kata kunci: Reciprocal Teaching, Hasil Belajar, Teknologi Dasar Otomotif. 
66 Dimas Ari Prasetyo, Wardan Suyanto

\section{PENDAHULUAN}

Proses pembelajaran adalah interaksi aktif antara guru dan peserta didik serta dapat dilakukan menggunakan perantara media maupun model pembelajaran (Sofyan, 2015; Martubi, 2009). Informasi yang didapatkan peserta didik tidak hanya bersumber dari guru saja. Apabila guru telah memberikan pengetahuan, akan tetapi peserta didik tidak menerimanya dengan baik, maka terdapat masalah yang terjadi. Menurut Rusman (2012:94)pembelajaran adalah suatu proses interaksi komunikasi antara sumber belajar, guru dan peserta didik Hasil dari interaksi aktif dapat dinyatakan dengan nilai hasil belajar yang didapat melalui tes/uji kompetensi. Dengan kata lain, proses pembelajaran yang baik belum tentu menghasilkan output yang semuanya baik pula.

Berdasarkan hasil observasi di kelas X TKRO 2 SMK Muhammdiyah 1 Bantul pada mata pelajaran TDO, kenyataannya peserta didik masih cenderung pasif dan malu mengungkapkan pendapatnya. Dalam model pembelajaran diskusi dan tanya jawab, guru mengarahkan peserta didik menggunakan handphone untuk mengakses beberapa sumber belajar. Faktanya setiap kelompok yang beranggotakan 4 peserta didik, hanya 1-2 yang mengakses sumber belajar dan yang lain memanfaatkan kesempatan sebagai media hiburan.

Ditemukan bahwa nilai Ulangan Harian (UH) kelas X TKRO 2 SMK Muhammadiyah 1 Bantul dari 32 peserta didik terdapat 23 mendapatkan nilai kurang dari KKM dan hanya 9 $(28,13 \%)$ mampu mencapai KKM. SMK Muhammdiyah 1 Bantul menetapkan KKM =78,00 untuk mata pelajaran TDO.

Permasalahan hasil belajar, dapat dimungkinkan karena model pembelajaran diskusi dan tanya jawab yang digunakan guru. Dengan guru memilih model pembelajaran yang sesuai dengan karakteristik peserta didik menjadikan proses pembelajaran yang baik. Selain itu, kurikulum 2013 menuntut peserta didik untuk aktif dan guru bertugas sebagai fasilitator dalam proses pembelajarannya.

Apabila hal ini terus dibiarkan, maka berdampak kepada mutu SMK Muhammadiyah 1 Bantul dan kualitas lulusan. Oleh karena itu, dibutuhkan implementasi model pembelajaran ysng baru dan belum pernah diterapkan serta dapat memecahkan permasalahan hasil belajar. Menurut hasil observasi, model pembelajaran Reciprocal Teaching belum pernah diterapkan di kelas X TKRO 2 SMK Muhammadiyah 1 Bantul. Huda (2015:216), model pembelajaran reciprocal teaching adalah model pembelajaran untuk meningkatkan pemahaman melalui strategi bertanya, mengklarifikasi, memprediksi, dan merangkum. Berdasarkan pengertian tersebut, meningkatnya pemahaman, maka akan berdampak terhadap hasil belajar.

Model pembelajaran reciprocal teaching memberikan kesempatan peserta didik untuk mempelajari materi terlebih dahulu, kemudian menjelaskan kembali materi yang dipelajari 
kepada peserta didik lain. Peran guru sebagai fasilitator dan pembimbing proses pembelajaran. Selain itu, membantu peserta didik membangun konsep berfikir secara mandiri.

\section{METODE}

Pelaksanakan Penelitian Tindakan Kelas (PTK) terdapat empat tahapan, yaitu perencanaan (planing), pelaksanaan (actuating), pengamatan (observing), dan refleksi (reflecting) (Arikunto, 2014:16-22). Lokasi di SMK Muhammadiyah 1 Bantul. Alamat lengkap SMK Muhammadiyah 1 Bantul. Dilaksanakan pada semester genap tahun ajaran 2019/2020 yaitu dari tanggal 14 Januari sampai dengan 4 Februari 2020.

Peserta didik kelas X TKRO 2 SMK Muhammadiyah 1 Bantul semester genap tahun ajaran 2019/2020. Lembar Observasi Pelaksanaan Model Pembelajaran Reciprocal Teaching dan tes hasil belajar. Teknik analisi data penelitian ini adalah teknik analisis data kuantitatif. Untuk analisis persentase ketuntasan hasil belajar dilihat dari banyaknya peserta didik mencapai KKM dari hasil tes hasil belajar.

Tabel 1. Kategori Ketuntasan Hasil Belajar

\begin{tabular}{cc}
\hline Persentase Ketuntasan & Kategori \\
\hline $80-100 \%$ & Sangat Baik \\
$66-79 \%$ & Baik \\
$56-65 \%$ & Cukup \\
$40-55 \%$ & Kurang \\
$<40 \%$ & Kurang Sekali \\
\hline \multicolumn{2}{c}{ (Arikunto \& Jabar, 2014:35) }
\end{tabular}

Untuk analisis pelaksanaan model Reciprocal Teaching berdasarkan checklist dan catatan pada lembar observasi pelaksanaan model pembelajaran reciprocal teaching. Indikator keberhasilan apabila persentase ketuntasan hasil belajar peserta didik sebesar 75\% (kategori baik).

\section{HASIL DAN PEMBAHASAN}

\section{HASIL}

Siklus I menggunakan KD 3.11 yakni memahami rangkaian kelistrikan sederhana dan Siklus II KD 3.15 yakni mengevaluai kerja baterai. Setiap siklus dilaksanaan dua kali pertemuan dan masing-masing pertemuan dilaksanakan selama 4 jam teori.

\section{Siklus I}

Siklus I dilaksanakan dua kali pertemuan, yaitu pada tanggal 14 dan 21 Januari 2020. Selama pelaksanaan siklus I, selama proses pembelajarannya guru melakukan tindakan implementasi model pembelajaran reciprocal teaching. 
68 Dimas Ari Prasetyo, Wardan Suyanto

Berdasarkan hasil pengamatan pelaksanaan model pembelajaran Reciprocal Teaching pada siklus I sudah dilaksanakan oleh guru dengan baik. Empat strategi model pembelajaran reciprocal teaching yaitu membuat pertanyaan (question generating), klarifikasi (clarifying), memprediksi (predicting), dan merangkum (summarizing) sudah dilaksanakan oleh guru, namun masih terdapat kekurangan. Tercatat pertemuan pertama pada siklus I terdapat 7 poin yang belum dilaksanakan oleh guru dengan baik. Untuk pertemuan kedua pada siklus I terdapat 6 poin yang belum dilaksanakan oleh guru dengan baik.

Pelaksanaan tes hasil belajar dilakukan pada pertemuan kedua pada siklus I.

Tabel 2. Hasil Belajar Siklus I

\begin{tabular}{llc}
\hline No & \multicolumn{1}{c}{ Hasil Siklus I } & Nilai \\
\hline 1 & Nilai tertinggi & 88,00 \\
2 & Nilai terendah & 52,00 \\
3 & KKM & 78,00 \\
4 & Peserta didik mencapai KKM & 16 \\
5 & Peserta didik belum mencapai KKM & 13 \\
6 & Persentase ketuntasan & $55,17 \%$ \\
\hline
\end{tabular}

Persentase ketuntasan hasil belajar peserta didik pada siklus I sebesar 55,17\% atau kategori "Kurang".

Berdasarkan refleksi siklus I terdapat beberapa langkah model pembelajaran reciprocal teaching yang belum dilaksanakan guru dengan baik dan belum tercapainya indikator keberhasilan. Dengan demikian diperlukan melakukan siklus II.

\section{Siklus II}

Siklus II dilaksanakan dua kali pertemuan yaitu pada tanggal 28 Janari dan 4 Februari 2020. Siklus II dilaksanakan berdasarkan adanya perbaikan pelaksanaan model pembelajaran reciprocal teaching dengan hasil refleksi siklus I.

Berdasarkan hasil pengamatan diketahui, guru berhasil melaksanakan seluruh langkah yang ada berdasarkan lembar observasi pelaksanaan model pembelajaran reciprocal teaching. Empat strategi utama model pembelajaran reciprocal teaching sudah dilaksanakan oleh guru dengan baik.

Pelaksanaan tes evaluasi hasil belajar dilakukan pada pertemuan kedua di siklus II.

Tabel 3. Hasil Belajar Siklus II

\begin{tabular}{llc}
\hline No & \multicolumn{1}{c}{ Hasil Siklus II } & Nilai \\
\hline 1 & Nilai tertinggi & 92,00 \\
2 & Nilai terendah & 56,00 \\
3 & KKM & 78,00 \\
4 & Peserta didik mencapai KKM & 24 \\
5 & Peserta didik belum mencapai KKM & 5 \\
6 & Persentase ketuntasan & $82,76 \%$ \\
\hline
\end{tabular}

Berdasarkan refleksi siklus II didapatkan, seluruh langkah model pembelajaran 
reciprocal teaching dapat dilaksanakan oleh guru. Persentase ketuntasan hasil belajar mencapai $82,76 \%$ atau pada kategori "Sangat Baik". Hal ini berarti indikator keberhasilan sudah dicapai pada siklus II. Dengan demikian penelitian dihentikan pada siklus II.

\section{PEMBAHASAN}

\section{Pelaksanaan Model Pembelajaran Reciprocal Teaching Siklus I}

Pelaksanaan model pembelajaran reciprocal teaching pada siklus I sudah dilaksanakan oleh guru dengan baik. Empat strategi utama model pembelajaran reciprocal teaching sudah dilaksanakan oleh guru dengan baik. Pada pertemuan pertama siklus I terdapat 7 langkah dan pertemuan kedua terdapat 6 langkah model pembelajaran reciprocal teaching yang masih belum dilaksanakan oleh guru dengan baik.

Berdasarkan tidak terlaksananya langkah tersebut, maka dilakukan identifikasi penyebabnya.

1) Pada pertemuan pertama, guru mata pelajaran yang mengawali proses pembelajaran dengan mengucapkan salam dan berdoa. Setelah itu, guru mata pelajaran memperkenalkan peneliti.

2) Tidak dilakukan sesi tanya jawab dikarenakan setelah kelompok presentasi, langsung dipersilahkan duduk kembali oleh guru.

3) Pada pertemuan pertama dilakukan tanya jawab antara guru dengan peserta didik tentang materi yang telah dipelajari. Sedangkan pertemuan kedua waktu tidak cukup dikarenakan diakhir pembelajaran dilakukan tes hasil belajar.

Berdasarakan identifikasi penyebab di atas maka diperlukan solusi, sebagai berikut.

1) Guru perlu mempersiapkan diri lebih matang dan memahami langkah-langkah model pembelajaran reciprocal teaching.

2) Merancang penggunaan waktu proses pembelajaran untuk setiap tahapan langkahnya.

\section{Pelaksanaan model pembelajaran reciprocal teaching siklus II}

Pelaksanaan model pembelajaran reciprocal teaching pada siklus II berjalan lebih baik dari siklus I. Empat strategi utama model pembelajaran reciprocal teaching sudah dilaksanakan guru dengan baik. Terbukti, siklus II pada pertemuan pertama dan kedua seluruh langkah model pembelajaran reciprocal teaching dapat terlaksana.

\section{Hasil Belajar}

Sudjana (2016:22) yang menyatakan bahwa hasil belajar adalah kemampuan yang dimiliki oleh peserta didik setelah menerima pengalaman belajarnya. Berdasarkan hasil penelitian, pada siklus I persentase ketuntasan hasil belajar belum mencapai indikator keberhasilan, yaitu sebesar 55,17\% atau kategori "Kurang". Terlepas dari belum maksimalnya pelaksanaan model pembelajaran reciprocal teaching, hasil belajar sudah menunjukkan adanya 
70 Dimas Ari Prasetyo, Wardan Suyanto

peningkatan. Dilihat data awal, ketuntasan belajar sebesar 28,13\% sedangkan siklus I sebesar $55,17 \%$. Pada siklus II persentase ketuntasan hasil belajar telah mencapai indikator yang telah ditetapkan. Persentase ketuntasan hasil belajar pada siklus II sebesar 82,76\% atau kategori "Sangat Baik".

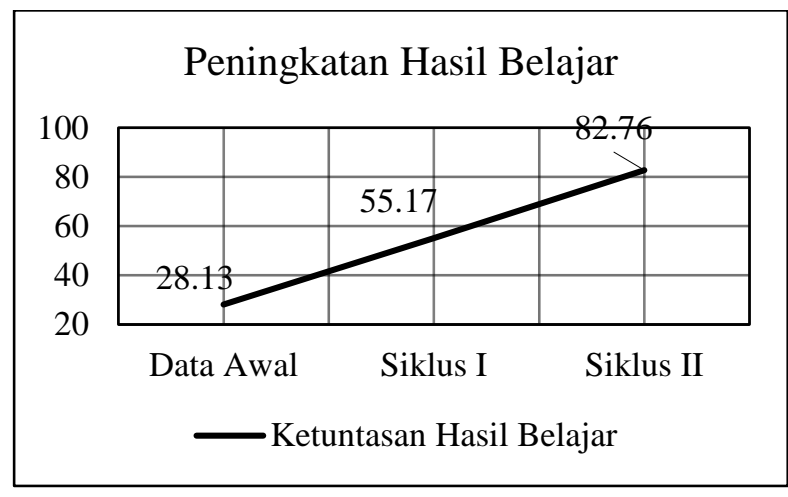

Gambar 1. Grafik Peningkatan Hasil Belajar

\section{Keberhasilan Model Pembelajaran Reciprocal Teaching dalam meningkatkan hasil belajar}

Implementasi model pembelajaran reciprocal teaching pada mata pelajaran Teknologi Dasar Otomotif (TDO) dapat meningkatkan hasil belajar peserta didik kelas X TKRO 2 SMK Muhammadiyah 1 Bantul. Peningkatan tersebut terlihat dari persentase ketuntasan hasil belajar.

Berdasarkan data awal ketuntasan hasil belajar sebesar 28,13\% (kategori kurang sekali). Setelah diterapkan model pembelajaran reciprocal teaching pada siklus I, ketuntasan hasil belajar meningkat menjadi 55,17\% (kategori kurang). Hal ini dikarenakan pada siklus I, langkah pelaksanaan model pembelajaran reciprocal teaching belum dilaksanakan seluruhnya. Selanjutnya, pada siklus II mengalami peningkatan ketuntasan hasil belajar menjadi 82,76\% (kategori sangat baik). Hal ini dikarenakan langkah pelaksanaan model pembelajaran reciprocal teaching seluruhnya terlaksana.

Berdasarkan penjelasan tersebut dapat diketahui bahwa implementasi model pembelajaran reciprocal teaching mampu meningkatkan hasil belajar peserta didik kelas $\mathrm{X}$ TKRO 2 SMK Muhammadiyah 1 Bantul pada mata pelajaran TDO. Zamtinah (2014: 242), bila terjadi proses konstruksi pengetahuan dengan baik, maka peserta didik dapat meningkatkan pemahamannya terhadap materi yang dipelajari. Keberhasilan penelitian ini juga mendukung penelitian sebelumnya yang dilakukan Efrata dan Estidarsini (2014), menyatakan bahwa hasil belajar peserta didik dapat meningkat dengan menggunakan model pembelajaran reciprocal teaching. Hal tersebut ditunjukkan setiap siklusnya terdapat peningkatan hasil belajar yakni ketuntasan siklus I sebesar $61,16 \%$ dan siklus II sebesar $81,08 \%$. 


\section{SIMPULAN DAN SARAN}

Dapat disimpulkan bahwa implementasi model pembelajaran reciprocal teaching di kelas X TKRO 2 SMK Muhammadiyah 1 Bantul mampu meningkatkan hasil belajar peserta didik pada mata pelajaran TDO. Data awal diketahui nilai ulangan harian didapatkan ketuntasan hasil belajarnya $28,13 \%$. Setelah diterapkannya model pembelajaran reciprocal teaching pada siklus I, ketuntasan hasil belajarnya menjadi 55,17\% (kategori "kurang”). Kemudian pada siklus II, ketuntasan hasil belajarnya menjadi 82,76\% (kategori “sangat baik").

1. Guru dapat mengimplementasikan model pembelajaran reciprocal teaching pada KD yang serupa untuk meningkatkan hasil belajar peserta didik pada mata pelajaran TDO.

2. Mengatur penggunaan waktu pada proses pembelajarannya agar semua langkah reciprocal teaching dapat terlaksana dengan baik.

Peneliti lain yang akan melakukan penelitian implementasi model pembelajaran reciprocal teaching, sebaiknya meneliti variabel yang belum diteliti yaitu hasil belajar dari aspek afektif ataupun mata pelajaran yang lainnya.

\section{DAFTAR PUSTAKA}

Arikunto, S. \& Jabar, C.S.A (2014). Evaluasi Program Pendidikan. Jakarta: Bumi Aksara.

Arikunto, S. (2014). Penelitian Tindakan Kelas. Jakarta: Bumi Aksara.

Estidarsini, N. (2014). Peningkatan Hasil Belajar dengan Menggunakan Metode Pembelajaran Terbalik (Reciprocal Teaching) pada Siswa Kelas X Teknik Gambar Bangunan untuk Mata Diklat Ilmu Bangunan Gedung di SMK Negeri 5 Surabaya. Jurnal JKPTB Vol 3 2014.

Huda, M. (2015). Model-model Pengajaran dan Pembelajaran. Yogyakarta: Pustaka Pelajar.

Martubi, M. (2009). Peningkatan Prestasi Belajar Matematika Lanjut Melalui Pembelajaran Menggunakan Modul dan Lembar Kerja dengan Soal Latihan Berjenjang. Jurnal Pendidikan Teknologi dan Kejuruan, 18(1), 85-102.

Nuh, M. (2004). Strategi-strategi Belajar. Surabaya: University Press Kampus UNESA.

Rusman. (2012). Belajar dan Pembelajaran Berbasis Komputer Mengembangkan Profesionalisme Abad 21. Bandung: Alfabeta.

Sofyan, H. (2015). Metodologi Pembelajaran Kejuruan : UNY Press. Yogyakarta.

Sudjana, N. (2016). Penilaian Hasil Proses Belajar Mengajar. Bandung: PT Remaja Rosdakarya. 
72 Dimas Ari Prasetyo, Wardan Suyanto

Zamtinah, H. (2014). Peningkatan Hasil Belajar Mata Kuliah Instalasi Listrik Melalui Pendekatan Learning Cycle Five "E” (LC 5 E). Jurnal JPTK Vol 22 Oktober 2014 